\title{
Development of Whitening Cosmetic Ingredients from Cudrania tricuspidata Stem Extract
}

\author{
Hyo Sun Han ${ }^{1,2}$, Soo-Yeon Kim³ ${ }^{3}$ Dae-Jin Lim ${ }^{4}$, Wan-Kyun Whang ${ }^{2 *}$ \\ ${ }^{1}$ Korea Institute of Dermatological Sciences, Seoul, Korea \\ ${ }^{2}$ College of Pharmacy, Chung-Ang University, Seoul, Korea \\ ${ }^{3}$ Department of Beauty Art, Doowon Technical University, Paju-si, Gyeonggi-do, Korea \\ ${ }^{4}$ Department of Cosmetology and Art, Soongsil Cyber University, Seoul, Korea
}

\author{
"Corresponding author: Wan-Kyun Whang, \\ College of Pharmacy, Chung-Ang University, \\ 84 Heukseok-ro, Dongjak-gu, Seoul 06974, \\ Korea \\ Tel.: +82 28205590 \\ Fax: +82 28167338 \\ Email: whang-wk@cau.ac.kr
}

Received July 12, 2016

Revised August 24, 2016

Accepted August 30, 2016

Published September 30, 2016

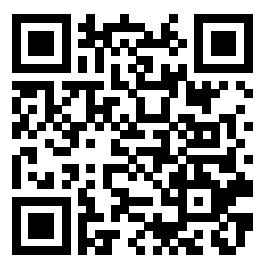

\begin{abstract}
Purpose: This study was conducted to investigate the possibility of Cudrania tricuspidata (C. tricuspidata) stem extract as whitening cosmetic material. Methods: We performed TLC and HPLC analysis to investigate the anti-oxidant compounds and its contents in $C$. tricuspidata stem extract fractions (hexane, ethyl acetate, butanol, and water). In order to evaluate anti-oxidant effects, radical and superoxide scavenging activities were conducted by using DPPH, ABTS free radicals and xanthine oxidases, respectively. In addition, we examined tyrosinase activity and cellular melanin content to verify the whitening effects of $C$. tricuspidata stem extract. Results: We found out that both ethyl acetate fraction and butanol fraction among the fractions of $C$. tricuspidata stem extract had anti-oxidant compounds. Our results pointed out that the active fractions have significant free radical and superoxide scavenging activities, and the fraction of ethyl acetate is the best. The ethyl acetate fraction $\left(\mathrm{IC}_{50} 24.4 \mathrm{ppm}\right)$ and butanol fraction $\left(\mathrm{IC}_{50} 88.3 \mathrm{ppm}\right)$ reduced tyrosinase activities and melanin content in a concentration-dependent manner. Conclusion: Through the results, $C$. tricuspidata stem extract has the potent as a cosmetic material which possess the anti-oxidant and whitening effects.
\end{abstract}

Keywords: Cudrania tricuspidata, Anti-oxidant, Tyrosinase, Melanin, Whitening cosmetic

\section{Introduction}

노화와 암을 비롯한 다양한 질환의 주요 원인으로 지목되고 있 는 활성산소종(reactive oxygen species, ROS)은 반응성이 커서 여 러 생체물질과 쉽게 반응하고, 체내 고분자들을 공격하여 세포 및 조직에 비가역적인 손상을 일으키거나 돌연변이, 세포독성 등을 초래한다(Squadrito \& Pryor, 1998). 최근 건강과 미(美)에 대한 관 심이 증가하면서, 향장분야에서도 피부 노화 및 트러블을 야기하 는 활성산소종을 억제하기 위한 노력을 기울이고 있는 추세이다 (Kim et al., 2011).

피부 노화 현상은 나이가 들어감에 따라 자연스럽게 생기는 내 인성 노화(intrinsic aging)와 자외선 등 환경에 노출되어 생기는 외 인성 노화(extrinsic aging) 즉, 광노화(photoaging)로 나눌 수 있 다. 내인성 노화의 경우 피부 표피와 진피의 결합 약화, 피부 각 질형성세포 분열 및 지질형성 능력의 저하 등의 특징을 나타내며
(Kim et al,, 2015), 외인성 노화는 자외선으로 인해 탄력을 유지시 키는 진피층의 콜라겐과 엘라스틴과 같은 탄력섬유를 손상시킨다 (Fisher et al,, 1999; Shim et al., 2008). 특히 피부가 많은 양의 자 외선을 받게 되면 항산화제가 감소되고 활성산소종으로 인한 세포 손상 및 노화가 발생된다(Kim et al., 2014). 자외선으로 인한 활성 산소종은 피부의 멜라닌 생성을 촉진하여 검버섯, 주근깨 등을 발 생시킬 뿐만 아니라 교원섬유의 절단, 비정상적인 교차결합, 세포 외기질 감소, 섬유아세포 기능저하 등으로 피부 탄력성 저하, 주름 생성 등의 피부 노화를 촉진시킨다(Jeong et al., 2010).

활성산소종이 유도하는 산화적 스트레스에 대항하기 위하여 피 부는 superoxide dismutase, catalase, glutathione peroxidase 등과 같은 항산화 방어망을 구축하여 활성산소 제거와 피부노화 억제를 조절하고 있다(Andersen et al., 1997). 활성산소를 조절 하기 위하여 합성 항산화제가 널리 사용되어 왔지만, 과량 섭취할 경우 간, 폐, 위 등에 심각한 부작용을 나타낼 수 있다는 안전성의 
논란과(Ramarathnam et al., 1995; Omaye et al., 1977), 웰빙이 라는 문화적 이슈로 인한 인공 합성물에 대한 인식의 변화로(Kim et al., 2011), 민간이나 한의학에서 질병예방 및 치료의 목적으로 이용하던 천연물을 활용하여 보다 안전한 향장제품의 개발이 활 발히 이루어지고 있다(Seo et al., 2013; Lee et al., 1998; Moure et al., 2001).

꾸지뽕나무(Curdrania tricuspidata)는 뽕나무과(Moraceae)에 속하는 낙엽활엽 소교목으로 우리나라를 비롯한 동아시아 지역에 주로 분포하고 있으며, 줄기에는 가시가 있고 9-10월에 붉은 열매 를 맺는 특징이 있다(Kim et al., 2009; Choi et al., 2009; Jung, 1965). 동의보감에는 자양, 강장 효능과 음위, 신체허약증, 불면 증 등에 꾸지뽕나무를 이용하였다는 기록이 있으며(Choi et al., 2009), 꾸지뽕나무 잎은 습진, 폐결핵, 타박상, 급성 관절염 등의 치료에, 줄기는 주로 부인병에, 열매는 청열과 양혈을 다스리는데 사용되었다(Kim et al., 2009; Joo \& Lim, 2009). 특히 꾸지뽕나 무를 물로 달여 먹으면 간암치료에 효과적인 것으로 알려져 있다 (Kim et al., 2000; Park et al., 1995).

꾸지뽕나무 연구와 관련하여 근피(뿌리껍질)에서 cudraxanthone $\mathrm{A}-\mathrm{O}$, cudraflavone A-D, euchrestaflavone C, cycloartocarpesin, populnin, quercimeritrin, 6-deoxyisojacareubin 등이 분 리되었으며, 줄기와 잎에서는 kaempferol, kaempferol-7O-glucopyranoside, naringen-7-O-glucopyranoside, $\beta$ -sitosterol, $\beta$-sitosterol glucoside, 5-O-methyl genistein 등 다양한 성분 연구가 보고된 바 있다(Kim et al., 1993; Lee et al., 1994; Nomura et al., 1983).

한편 꾸지뽕나무에 관한 생리활성 연구도 꾸준히 진행되어, 꾸 지뽕나무의 과산화 지질 생성 억제(Cha et al., 1999; Cha et al., 2000; Kim et al., 2000), 항염증(Ottersen et al., 1977), 간보호 (Jeong \& Kim, 1999), 골관절염 억제(Nam et al., 2013), 항균 (Ottersen et al,, 1977), 세포독성(Lee et al., 1996), 고혈압(Kang et al., 2002), 항산화(Cha et al., 1999; Cha et al., 2000; Lee et al., 2007) 등의 생리활성 연구가 발표되었다.

꾸지뽕나무의 잎, 열매, 뿌리, 가지 등을 이용한 실험은 대부분 의약품 및 식품 자원으로서의 항산화, 항염 등 생리활성에 관한 논 문이 대부분을 차지하고 있으며 아직 꾸지뽕나무 가지 추출물을 이 용한 미백 기능성 화장품 원료에 대한 실험 연구는 보고 된 바가 없 다. 따라서 본 연구는 천연물인 꾸지뽕나무의 자원화 및 응용기술 을 개발하기 위한 기초자료로서 꾸지뽕나무 가지 추출물의 항산화 및 미백 효과를 검증하여 미백 기능성 화장품 원료로의 개발 가능 성을 알아보고자 한다.

\section{Methods}

\section{1. 추출 및 분획}

본 연구에 사용된 꾸지뽕나무(Cudrania tricuspidata) 가지는 2011년 2월 서울 경동약령시장(Korea)에서 구입하여 사용하였다. 건조 및 분쇄한 꾸지뽕나무 가지 $3 \mathrm{~kg}$ 을 100\% ethanol (EtOH) 18 $\mathrm{L}$ 에 침적시키고 $24 \mathrm{~h}$ 동안 상온에서 교반하여 추출한 후 여과하 였다. 위와 같은 방법으로 5 회 더 반복한 후 이를 감압 농축 및 동 결 건조하여 총 $236 \mathrm{~g}$ 의 $\mathrm{EtOH}$ 추출물을 얻었다. $\mathrm{EtOH}$ 추출물을 증류수에 현탁한 후 용매분획을 실시하여 각각 hexane fraction (14.22 g), ethyl acetate fraction (20.74 g), butanol fraction $(68.34 \mathrm{~g})$, water fraction (132.58 g)을 얻었다.

\section{2. 항산화 활성 평가}

1) 항산화 물질 분석

(1) 박층크로마토그래피(thin layer chromatography, TLC)

항산화 물질로 알려진 rutin, dihydroquercetin 7-O- $\beta$ -D-glucopyranoside, dihydrokaempferol $7-\mathrm{O}-\beta-\mathrm{D}-$ glucopyranoside의 함유여부를 확인하기 위해, 각각의 꾸지뽕나 무 가지 분획물 가루 $0.1 \mathrm{~g}$ 을 70\% methanol (MeOH) $1 \mathrm{~mL}$ 에 녹 여 실리카겔이 처리된 박층판에 $20 \mu \mathrm{L}$ 씩 점적하였다. 점적한 순 서는 hexane fraction, ethyl acetate fraction, butanol fraction, water fraction, dihydroquercetin $7-\mathrm{O}-\beta-\mathrm{D}-$ glucopyranoside, dihydrokaempferol $7-\mathrm{O}-\beta-\mathrm{D}-$ glucopyranoside, arbutin, rutin 이다. $\mathrm{CHCl}_{3}: \mathrm{MeOH}: \mathrm{H}_{2} \mathrm{O}=70: 30: 4$ 를 전개용매로 하여 10 $\mathrm{cm}$ 전개한 다음 $\mathrm{UV} 254 \mathrm{~nm}$ 및 $10 \% \mathrm{H}_{2} \mathrm{SO}_{4}$ 에서 박층판을 확인하였다.

\section{(2) HPLC를 통한 항산화 물질 함량 분석}

꾸지뽕나무 가지 $\mathrm{EtOH}$ 추출물 $1 \mathrm{mg}$ 에 $70 \% \mathrm{EtOH} 10 \mathrm{~mL}$ 을 넣고 $2 \mathrm{~h}$ 동안 초음파 추출한 후 여과하였다. 위와 같은 방법으로 2 번 더 반복한 다음 감압 농축하여, 농축한 추출물을 $\mathrm{MeOH} 5 \mathrm{~mL}$ 에 녹인 후 membrane filter $(0.45 \mu \mathrm{m})$ 로 정제하여 HPLC (Waters, USA) 분석을 실시하였다. Kromasil 100-5-C18 column (4.6× 250

\section{Table 1. HPLC analytical conditions}

\begin{tabular}{cccc}
\hline Detector & \multicolumn{3}{c}{ UV $(210 \mathrm{~nm})$} \\
\hline Column & \multicolumn{2}{c}{ Kromasil } & $100-5-\mathrm{C} 18(4.6 \times 250 \mathrm{~mm})$ \\
& Time $(\mathrm{min})$ & Water & Acetonitrile \\
& 0 & 90 & 10 \\
Mobile phase & 20 & 70 & 30 \\
& 30 & 50 & 50 \\
& 40 & 0 & 100 \\
Flow rate & \multicolumn{3}{c}{$10 \mathrm{~mL} / \mathrm{min}$} \\
Injection & \multicolumn{3}{c}{} \\
\hline
\end{tabular}


$\mathrm{mm}$; Kromasil, Netherlands)을 사용하고, 이동상으로는 $\mathrm{MeOH}$ 과 3 차 증류수를 $20: 80$ 의 비율로 혼합하여 사용하였으며, $1 \mathrm{~mL} /$ $\min$ 의 유속을 유지하며 UV $210 \mathrm{~nm}$ 에서 측정하였다(Table 1). 표준액은 rutin, dihydroquercetin $7-\mathrm{O}-\beta-\mathrm{D}-$ glucopyranoside, dihydrokaempferol 7-O- $\beta-\mathrm{D}$-glucopyranoside $1 \mathrm{mg}$ 을 정제수 에 녹여 membrane filter $(0.45 \mu \mathrm{m})$ 로 정제한 후 사용하였다.

\section{2) Radical을 이용한 항산화능 평가}

꾸지뽕나무 가지의 항산화능을 측정하기 위하여 DPPH free radical scavenging assay와 $\mathrm{ABTS}^{+}$radical scavenging assay를 이용하였다. Free radical인 1,1-diphenyl-2picrylhydrazyl (DPPH; Sigma-Aldrich, USA)는 $518 \mathrm{~nm}$ 에서 광 흡수를 나타내는 진한 보라색 화합물이며 radical 소거활성이 있 는 항산화 물질에 의해 정량적으로 노란색으로 탈색되므로 항산화 활성을 쉽게 측정할 수 있어 항산화제 검색에 널리 사용되고 있다. 꾸지뽕나무 가지 분획물을 농도별로 조제한 후 각 시료 $20 \mu \mathrm{L}$ 에 $0.1 \mathrm{mM}$ DPPH 용액 $180 \mu \mathrm{L}$ 을 가한 후 Maxi Mix II vortex mixer (M37615; Barnstead/Thermolyne, USA)로 $10 \mathrm{~s}$ 동안 혼합한 후 $37^{\circ} \mathrm{C}$ 에서 $30 \mathrm{~min}$ 반응시킨다. 이 후 UV/Vis spectrophotometer (Optizen 2120UV; Mecasys, Korea)를 이용하여 $518 \mathrm{~nm}$ 에서 흡광 도를 측정하였다.

한편, $\mathrm{ABTS}^{+}$radical scavenging assay는 2,2'-azino-bis(3ethylbenzothiazoline-6-sulfonic acid) diammonium salt (ABTS; Sigma-Aldrich, USA)가 potassium sulfate와 반응하 여 생기는 $\mathrm{ABTS}^{+}$radical의 소거능을 통해 시료의 항산화능을 평 가하는 방법이다(Arnao et al., 2001). 꾸지뽕나무 가지 분획물을 농도별로 조제한 후 각 시료 $50 \mu \mathrm{L}$ 에 $7.4 \mathrm{mM}$ ABTS와 $2.6 \mathrm{mM}$ potassium sulfate 혼합액 $950 \mu \mathrm{L}$ 를 첨가하여 $732 \mathrm{~nm}$ 에서 흡광 도를 측정하였고, 양성대조군으로는 수용성 항산화제로 잘 알려진 L-ascorbic acid (Sigma-Aldrich, USA)를 사용하였다.

\section{3) Hypoxanthine/xanthine oxidase system을 이용한 superoxide 항산화능 평가}

인체 내에서 uric acid 생성에 관여하는 xanthine oxidase 는 hypoxanthine, xanthine을 기질로 하여 uric acid를 생성한 다. 하지만 이 과정에서 superoxide가 생성되어 이는 인체 내 산 화적 손상을 입힌다. 이러한 생체 내 과정을 생체 밖 in vitro 에서 재현하여, 이 과정에서 대상 시료가 superoxide를 얼마 나 소거하는지를 확인함으로써 항산화 효과를 가늠해 볼 수 있 다. $50 \mathrm{mM}$ potassium phosphate buffer (PPB, $\mathrm{pH}$ 7.4), $1 \mathrm{mM}$ ethylenediaminetetraacetic acid (EDTA), $0.6 \mathrm{mM}$ hypoxanthine, $0.2 \mathrm{mM}$ nitro blue tetrazolium (NBT)을 이용하여 reaction mixture를 만들었다. 제조된 mixture $400 \mu \mathrm{L}$ 에 꾸지뽕나무 가지 분획물을 $5 \mu \mathrm{L}$ 씩 가한 후, xanthine oxidase $(100 \mathrm{mU} / \mathrm{mL}) 100 \mu$
$\mathrm{L}$ 을 넣어 $37^{\circ} \mathrm{C}$ 에서 $10 \mathrm{~min}$ 동안 반응시키고 $595 \mathrm{~nm}$ 에서 흡광도 를 측정하였다. 양성대조군으로는 xanthine oxidase의 비경쟁적 길항제로 알려진 allopurinol (Sigma-Aldrich, USA)을 이용하였다.

\section{3. 미백 활성 평가}

1) Tyrosinase 활성 억제능 평가

Tyrosinase는 멜라닌 합성에 있어 중요하게 작용하는 효소로, 기질인 tyrosine이 4-dihydroxyphenylalanine (DOPA), DOPA quinone으로 산화되는 과정을 촉매하는데, 이 과정에서 멜라닌 흡 광도를 측정함으로써 시료의 tyrosinase 활성 억제능을 검토하는 방 법으로 미백 활성 연구에 이용되고 있다(Kim et al., 2015). $10 \mathrm{mM}$ sodium phosphate buffer (pH 6.8)에 $1.7 \mathrm{mM} \mathrm{L}$-tyrosine을 0.3 $\mathrm{mg} / \mathrm{mL}$ 가 되도록 완전히 녹인 후, L-tyrosine $450 \mu \mathrm{L}$ 에 꾸지뽕나 무 가지 분획물을 농도별로 $5 \mu \mathrm{L}$ 첨가하였다. Mushroom tyrosinase $(250 \mathrm{U} / \mathrm{mL}) 50 \mu \mathrm{L}$ 을 넣고 혼합하여 $37^{\circ} \mathrm{C}$ 에서 $60 \mathrm{~min}$ 동안 반응 시킨 다음 $475 \mathrm{~nm}$ 에서 흡광도를 측정하였다. 양성대조군으로 kojic acid (Sigma-Aldrich, USA)를 사용하여 미백 활성을 측정하였다.

\section{2) 세포 생존율 평가}

꾸지뽕나무 가지 분획물의 세포 생존율을 확인하기 위하여 B16F10 murine melanoma cell (한국세포주은행, Korea)을 이용하 여 crystal violet assay를 실시하였다. 24 well plate에 B16F10을 2 $\times 10^{4}$ cells/well 농도로 분주하여 $37^{\circ} \mathrm{C}, 5 \% \mathrm{CO}_{2}$ 조건에서 $24 \mathrm{~h}$ 동 안 배양하였다. 다음날 serum free 배지를 이용하여 $1,10,50,100$ $\mathrm{ppm}$ 가 최종농도가 되도록 꾸지뽕나무 가지 분획물을 $1 \mu \mathrm{L}$ 씩 넣 고 $24 \mathrm{~h}$ 동안 배양하였다. 배지를 모두 제거하고 모든 well에 $0.1 \%$ crystal violet $0.5 \mathrm{~mL}$ 을 넣어 $5 \mathrm{~min}$ 동안 세포를 염색하였다. 증류 수로 4 회 세척한 후 $95 \% \mathrm{EtOH}$ 을 $1 \mathrm{~mL}$ 씩 넣어 실온에서 $15 \mathrm{~min}$ 동 안 균질혼합하면서 추출한 후 ELISA microplate reader (Versamax; Molecular devices, USA)로 $590 \mathrm{~nm}$ 에서 흡광도를 측정하였다.

\section{3) Melanin 생합성 억제능 평가}

$\mathrm{B} 16 \mathrm{~F} 10$ 을 6 well plate에 $5 \times 10^{4}$ cells/well 농도로 분주하여 $37^{\circ} \mathrm{C}, 5 \% \mathrm{CO}_{2}$ 조건에서 $24 \mathrm{~h}$ 동안 배양하고, 다음날 phenol red free DMEM $3 \mathrm{~mL}$ 로 교체하여 control을 제외한 5 개 well에 $\alpha$ -melanocyte stimulating hormone ( $\alpha-\mathrm{MSH})$ 를 $1 \mu \mathrm{L}$ 씩 처리하여 멜라닌 생성을 유도하였다. Control과 $\alpha-\mathrm{MSH}$ 로 처리한 well을 제 외한 나머지 well에 $1 \mathrm{ppm}$ 농도의 각 꾸지뽕나무 가지 분획물을 3 $\mu \mathrm{L}$ 씩 처리 한 후 $72 \mathrm{~h}$ 동안 배양하였다. 각 well마다 세포를 포집 하여 $15,000 \mathrm{rpm}, 5 \mathrm{~min}$ 동안 원심분리 한 후 상층액만 분리하여 $400 \mathrm{~nm}$ 에서 흡광도를 측정하였다. 각 well마다 세포수를 세어 흡 광도 값과 비교하여 멜라닌 생성량을 산출하였다. 


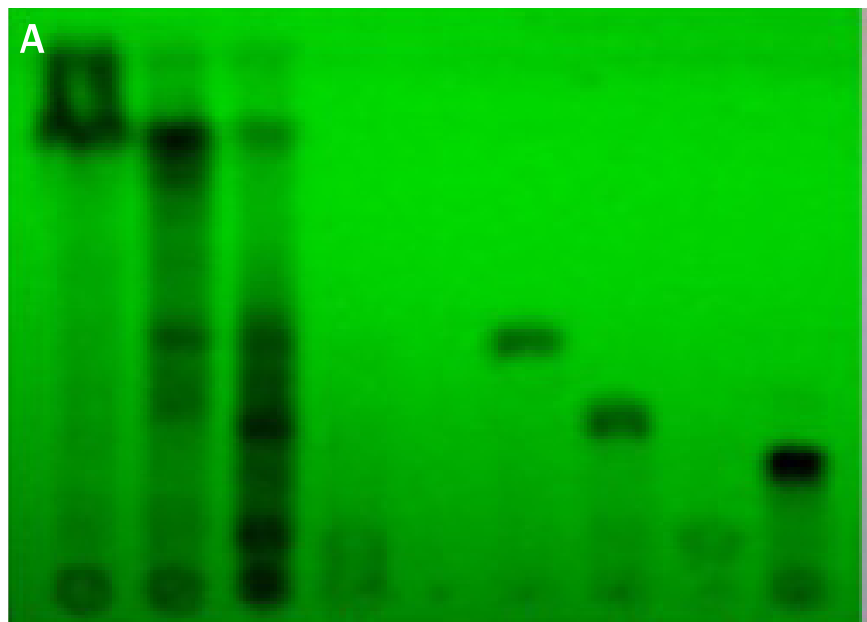

(a) (b) (c) (d)

(e) (f) (b)

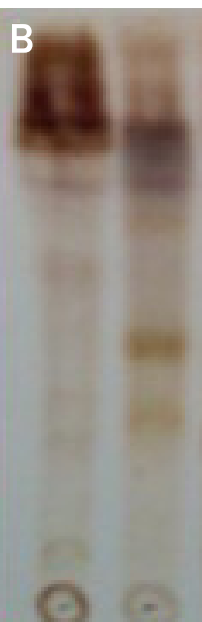

(a) (b)

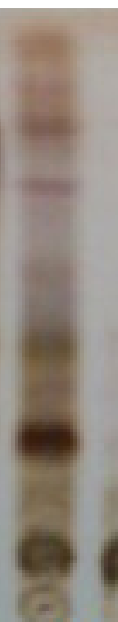

(c) (d)

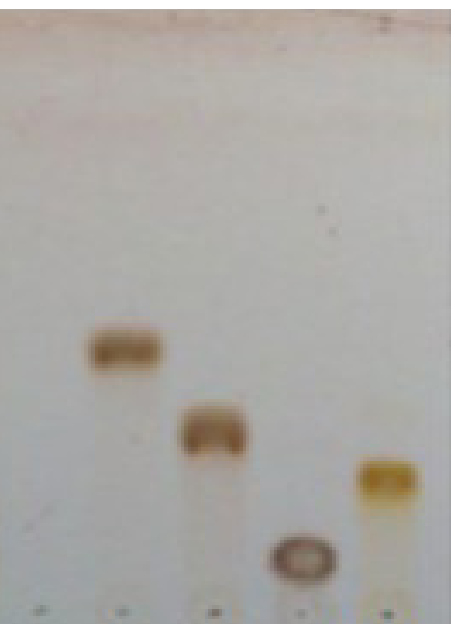

(C) (f) (9) (b)

Figure 1. TLC analyses of Cudrania tricuspidata (C. tricuspidata) stem extract fractions.

The anti-oxidant compounds in C. tricuspidata stem extract fractions were analyzed by TLC with $254 \mathrm{~nm}$ UV (A) and 10\% $\mathrm{H}_{2} \mathrm{SO}_{4}$ (B). (a); hexane fraction, (b); ethyl acetate fraction, (C); butanol fraction, (d); water fraction, (e); dihydroquercetin 7-O- $\beta$-D-glucopyranoside, (f; dihydrokaempferol 7-O- $\beta$-D-glucopyranoside, (9); arbutin, (h); rutin.

\section{4. 자료분석 및 통계적 검정}

실험 결과는 평균표준오차로 표기하였으며, 실험 결과의 통계 학적 유의성은 Student's t-test로 검정하였고 p 값이 $5 \%$ 미만일 경우 통계적으로 유의한 것으로 판정하였다( $\left.{ }^{*} p<.05\right)$.

\section{Results and Discussion}

\section{1. 항산화 물질 및 함량 분석}

꾸지뽕나무 가지 분획물에서 항산화물질인 rutin, dihydroquercetin $7-\mathrm{O}-\beta-\mathrm{D}-$ glucopyranoside, dihydrokaempferol $7-\mathrm{O}-\beta$ -D-glucopyranoside의 함유여부를 확인하기 위해 TLC를 수행 하였다. UV $254 \mathrm{~nm}$ 및 $10 \% \mathrm{H}_{2} \mathrm{SO}_{4}$ 에서 박층판을 확인한 결과, 표준품과 비교하였을 때 꾸지뽕나무 가지 hexane, ethyl acetate, butanol, water 분획물 중 ethyl acetate와 butanol 분획물에 서 항산화 물질의 함유가 뚜렷하게 나타났다. Ethyl acetate 분 획물에서는 dihydroquercetin 7-O- $\beta-\mathrm{D}$-glucopyranoside, dihydrokaempferol 7-O- $\beta-\mathrm{D}$-glucopyranoside이 나타 났으며, butanol 분획물에서는 dihydroquercetin 7-O$\beta-\mathrm{D}$-glucopyranoside, dihydrokaempferol 7-O- $\beta$ -D-glucopyranoside 및 rutin이 뚜렷하게 나타났다(Figure 1).

꾸지뽕나무 가지 분획물에서의 rutin, dihydroquercetin 7-O- $\beta-\mathrm{D}-$ glucopyranoside, dihydrokaempferol 7-O- $\beta$ -D-glucopyranoside 함유여부 및 함량을 HPLC 분석을 통해 확 인한 결과, 꾸지뽕나무 가지 $\mathrm{EtOH}$ 추출물 $1 \mathrm{~g}$ 당 dihydroquercetin 7-O- $\beta$-D-glucopyranoside은 $16.54 \mathrm{mg}$, dihydrokaempferol
7-O- $\beta-\mathrm{D}-$ glucopyranoside은 $14.61 \mathrm{mg}$, rutin은 $34.65 \mathrm{mg}$ 함 유되어 있었다(Figure $2 \mathrm{~A}$ ). TLC 결과와 마찬가지로 ethyl acetate 분획물에서는 dihydroquercetin 7-O- $\beta-\mathrm{D}$-glucopyranoside, dihydrokaempferol 7-O- $\beta-\mathrm{D}-$ glucopyranoside이 나타났고 (Figure 2B), butanol 분획물에서는 dihydroquercetin 7-O$\beta-\mathrm{D}$-glucopyranoside, dihydrokaempferol $7-\mathrm{O}-\beta$ -D-glucopyranoside 및 rutin이 나타났다(Figure $2 \mathrm{C}$ ).

TLC 및 HPLC 분석을 통해 꾸지뽕나무 가지 분획물이 rutin, dihydroquercetin 7-O- $\beta-\mathrm{D}-$ glucopyranoside, dihydrokaempferol 7-O- $\beta-\mathrm{D}-$ glucopyranoside을 포함하고 있다는 것을 확인함 으로써, 꾸지뽕나무 잎에서 분리한 dihydroquercetin 7-O- $\beta-\mathrm{D}$ -glucopyranoside의 항산화 효과(Chon et al., 2005), quercetin 과 kaempferol 및 그 배당체들의 생리활성(Cho et al., 2003; Chon et al., 2005) 등의 기존 연구를 바탕으로 꾸지뽕나무 가지에서도 항산화 효과 및 다양한생리활성을 나타낼 것이라고 예상할수 있었다.

\section{Radical을 이용한 항산화능 평가}

꾸지뽕나무 가지의 항산화 효능을 확인하기 위하여 분획물을 최종농도 $1,10,50,100 \mathrm{ppm}$ 로 처리하여 실험을 수행하였다. 꾸 지뽕나무 가지의 $\mathrm{EtOH}$ 추출물 각 분획의 $\mathrm{DPPH}$ free radical 소 거능을 확인한 결과, $100 \mathrm{ppm}$ 농도에서 radical 소거능이 각각 ethyl acetate (80.6\%), butanol (67.6\%), water (42.5\%), hexane (20.3\%) 순으로 나타났으며, 각 분획별로 농도 의존적으로 황 산화 효과가 증가하였다. 특히 ethyl acetate는 양성대조군인 L-ascorbic acid (88.3\%)와 비교해 비교적 우수한 항산화능을 나타내었다(Figure 3A). 

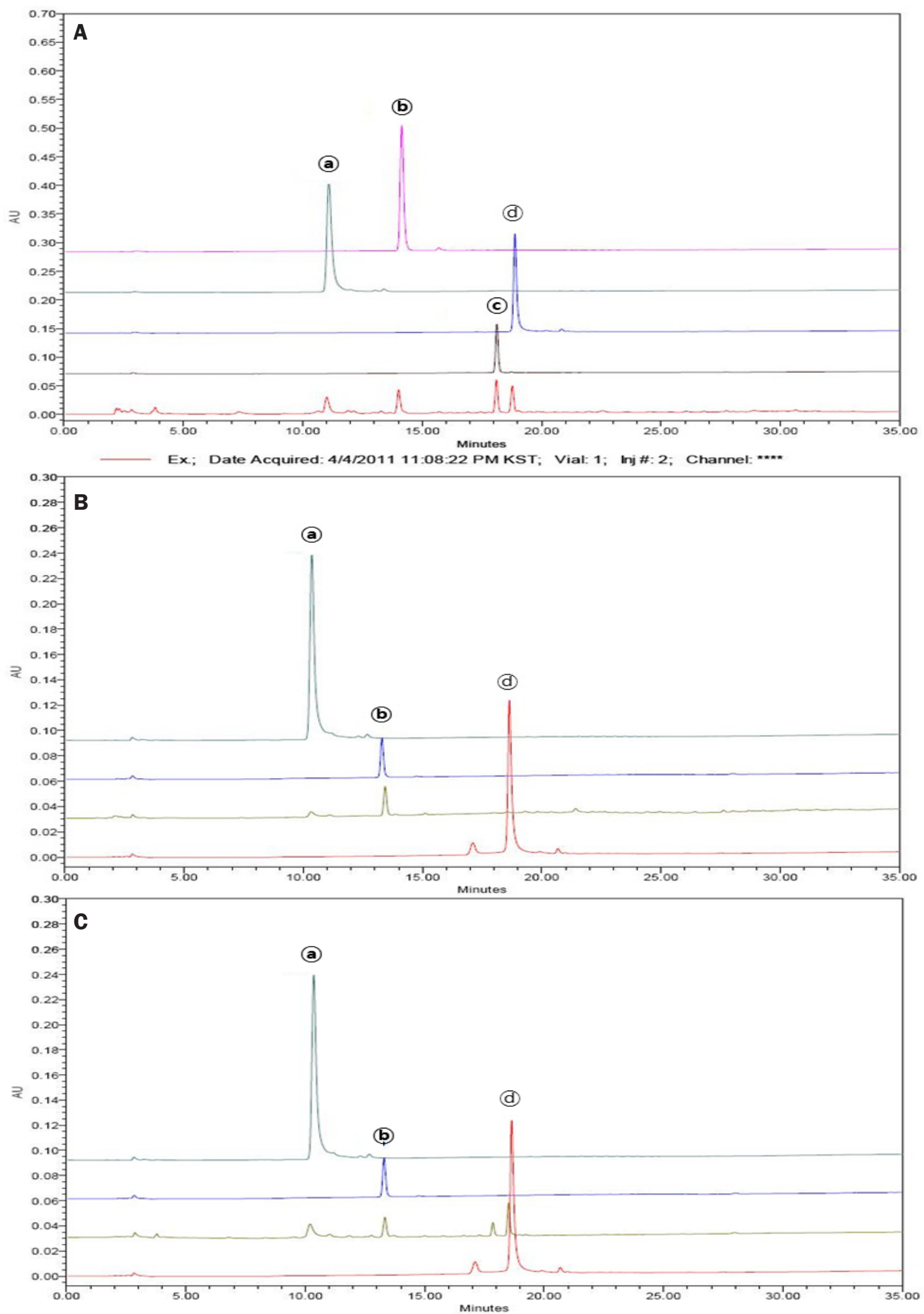

Figure 2. The HPLC analyses of anti-oxidant compounds in C. tricuspidata stem EtOH extract and its fractions.

The anti-oxidant compounds and its contents in C. tricuspidata stem EtOH extract (A), ethyl acetate fraction (B), and butanol fraction (C) were analyzed by HPLC. (a); dihydroquercetin 7-O- $\beta$-D-glucopyranoside, (b); dihydrokaempferol 7-0- $\beta$-Dglucopyranoside, (C; arbutin, @); rutin. 

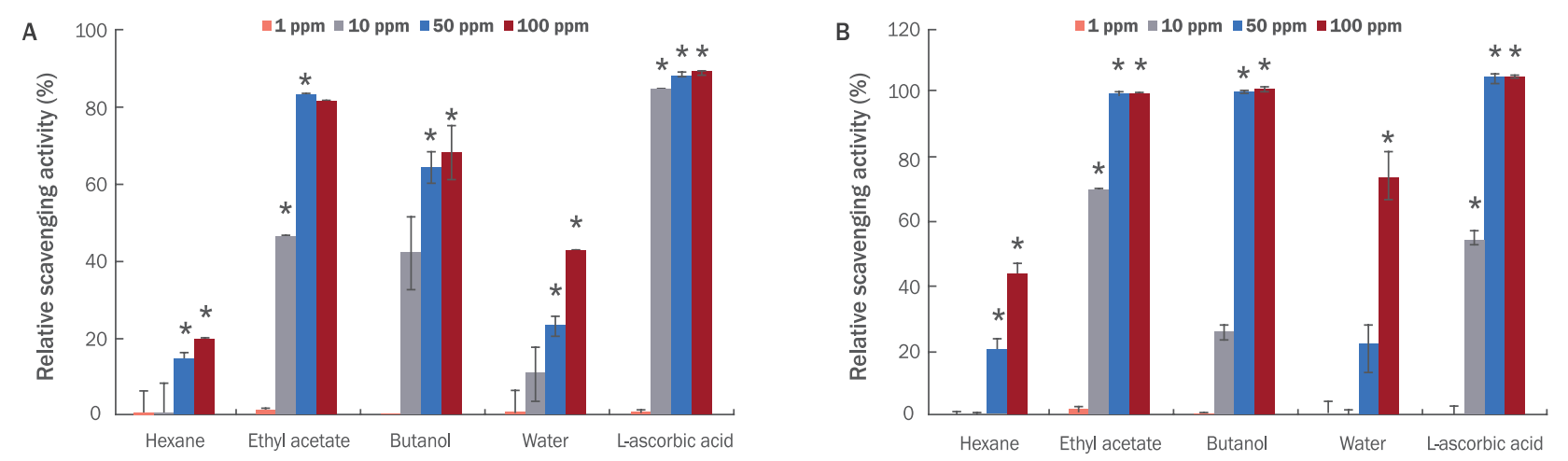

Figure 3. The anti-oxidant effects of $\boldsymbol{C}$. tricuspidata fractions in DPPH and ABTS ${ }^{+}$radical scavenging activities.

Free radical scavenging assays were conducted to investigate the anti-oxidant effects of $C$. tricuspidata fractions. (A) Effect of $C$. tricuspidata fractions on DPPH radical scavenging assay. (B) Effect of $C$. tricuspidata fractions on ABTS ${ }^{+}$ radical scavenging assay. L-ascorbic acid was used as a positive control. Values represent the mean \pm S.D. of three independent experiments. Statistical significance is indicated $\left({ }^{*} p<.05\right.$, compared with control).

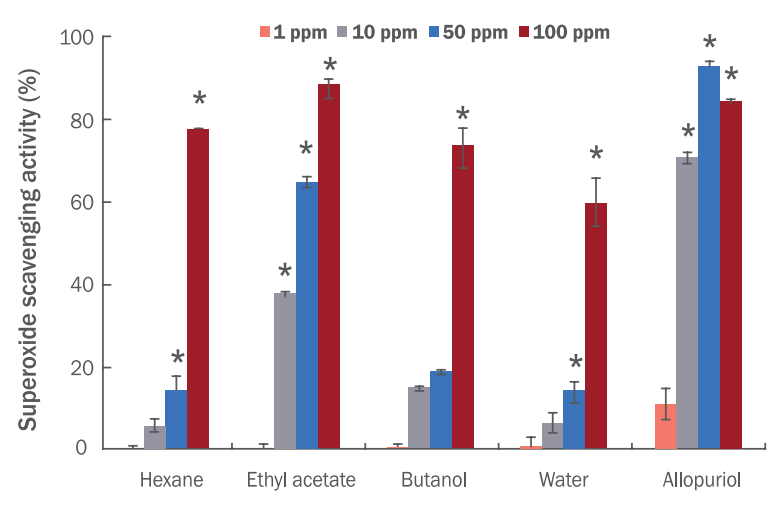

Figure 4. Superoxide scavenging activities of $C$. tricuspidata stem extract fractions.

Superoxide scavenging activity was determined via hypoxanthin/xanthine oxidase system. Allopurinol was used as a positive control. Values represent the mean \pm S.D. of three independent experiments. Statistical significance is indicated $\left({ }^{*} p<.05\right.$, compared with control).

한편, $\mathrm{ABTS}^{+}$radical scavenging activity에서는, ethyl acetate 및 butanol $50 \mathrm{ppm}$ 이상의 농도에서 radical 소거능이 거 의 $100 \%$ 로 L-ascorbic acid와 유사한 항산화 효과를 나타냈으며, 각 분획별로 농도 의존적으로 항산화 효과가 증가하였다(Figure $3 \mathrm{~B})$. Radical을 이용한 항산화능 측정 결과를 통해, 꾸지뽕나무의 ethyl acetate 및 butanol 분획물이 다른 분획물에 비해 높은 항산 화 효능을 나타내며 이는 TLC 및 HPLC 분석과도 유사한 결과임을 확인하였다.

\section{Superoxide 항산화능 평가}

꾸지뽕나무 가지의 분획물을 농도별로 조제하여 superoxide 항 산화능을 측정하였다. 각각의 분획물을 처리하여 superoxide 소거

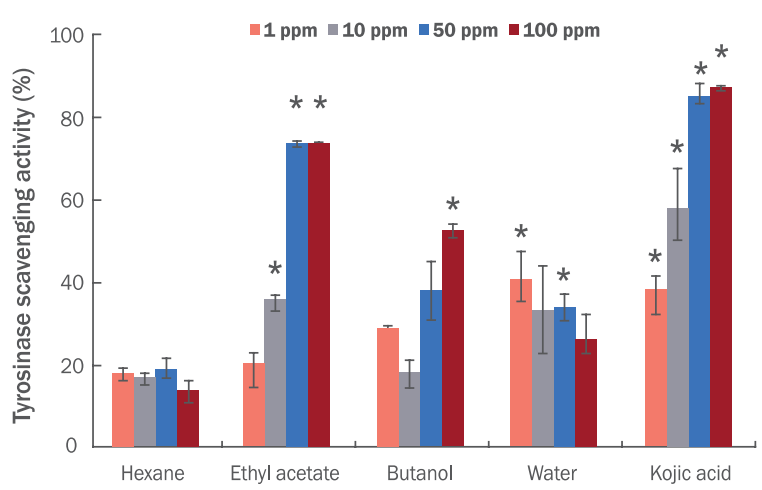

Figure 5. Inhibitory effects of $\boldsymbol{C}$. tricuspidata stem extract fractions on tyrosinase.

Tyrosinase inhibition activities of hexane, ethyl acetate, butanol, and water fractions of $C$. tricuspidata extract were individually measured at different concentrations of $1,10,50$, and $100 \mathrm{ppm}$. Kojic acid was used as a positive control. Values represent the meantS.D. of three independent experiments. Statistical significance is indicated ( ${ }^{*} p<.05$, compared with control).

능을 확인한 결과, ethyl acetate 분획물의 superoxide 소거능이 가 장 우수하였으며, 대체적으로 ethyl acetate〉hexane>butanol >water 분획 순으로 농도 의존적으로 항산화 활성이 증가하였다. 특히 ethyl acetate 분획물 $\mathrm{IC}_{50}$ 값은 $26.4 \mathrm{ppm}$ 으로 양성대조군으로 사 용된 allopurinol (xanthine oxidase inhibitor)의 $\mathrm{IC}_{50} 16 \mathrm{ppm}$ 에 비 해 다소 낮은 항산화 활성을 나타내었으나, 꾸지뽕나무 가지 분획 물 중에서는 가장 높은 항산화 활성을 보였다(Figure 4).

\section{Tyrosinase 활성 억제능 평가}

꾸지뽕나무 가지의 tyrosinase 활성 억제능을 확인하기 위 해 분획별로 최종농도가 $1,10,50,100 \mathrm{ppm}$ 이 되도록 처리하 

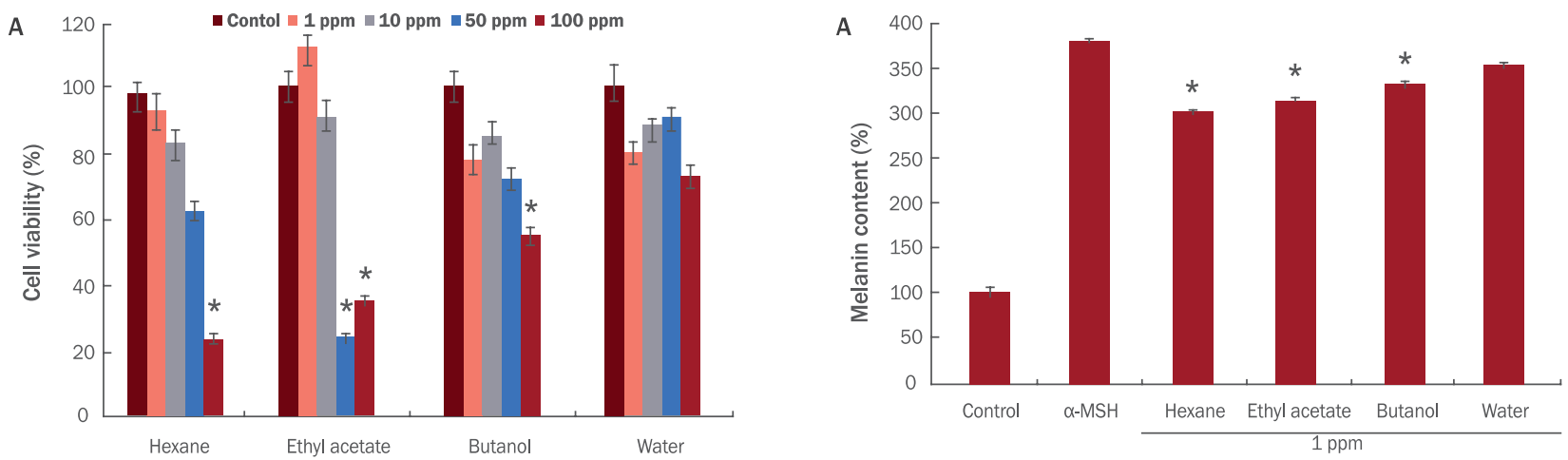

Figure 6. Effects of $\boldsymbol{C}$. tricuspidata stem extract fractions on cell viability (A) and melanin content (B) in B16F10 cells.

(A) The cell viability was determined by crystal violet assay after treatment with hexane, ethyl acetate, butanol, and water fractions of $C$. tricuspidata stem extract at different concentrations of 1, 10, 50, and $100 \mathrm{ppm}$ for $24 \mathrm{~h}$. (B) B16F10 cells were treated with $1 \mathrm{ppm}$ of those fractions to confirm the melanin content. Values represent the mean \pm S. D. of three independent experiments. Statistical significance is indicated $\left({ }^{*} p<.05\right.$, compared with $\alpha$-MSH treated cells).

여 실험을 진행하였다. 꾸지뽕나무 가지 분획물 중 ethyl acetate $\left(\mathrm{IC}_{50} 24.4 \mathrm{ppm}\right)$ 는 양성대조군인 kojic acid의 $\mathrm{IC}_{50} 9.3 \mathrm{ppm}$ 에 비교해 비교적 우수한 tyrosinase 활성 억제 효과를 보였다. Butanol에서는 $100 \mathrm{ppm}$ 농도에서 tyrosinase 활성 억제 효과를 나타냈으나( $\left.\mathrm{IC}_{50} 88.3 \mathrm{ppm}\right)$, hexane과 water에서는 효과를 관찰 할 수 없었다(Figure 5).

\section{Melanin 생합성 억제능 평가}

꾸지뽕나무 가지 분획물의 멜라닌 생합성 억제능을 평가하기 위하여 먼저 $\mathrm{B} 16 \mathrm{~F} 10$ 세포 생존율을 확인하였다. Crystal violet assay를 이용하여 세포 생존율을 확인한 결과, 꾸지뽕나무 가지 의 hexane, ethyl acetate, butanol, water 분획물 모두 농도의존 적으로 세포 독성이 증가하는 경향을 보였다. 따라서 분획물의 처 리 농도 중에서 최소 농도인 $1 \mathrm{ppm}$ 으로 실험을 진행함으로써 세 포 독성으로 인한 실험 결과에 미치는 영향을 줄이고자 하였다 (Figure 6A).

꾸지뽕나무 가지 분획물이 $\alpha-\mathrm{MSH}$ 에 의해 유도된 $\mathrm{B} 16 \mathrm{~F} 10$ 세포의 멜라닌 생합성에 미치는 영향을 확인하기 위하여, 세포 생존율 측정결과를 토대로 최소 농도인 $1 \mathrm{ppm}$ 으로 처리하여 멜 라닌 생합성량을 확인하였다. 멜라닌의 흡광도 값(O.D.)과 세 포 수를 보정해서 $\mathrm{X}=(\mathrm{Y}-0.0123) / 0.0104$ 로 계산하여 분석한 결과 $\alpha-\mathrm{MSH}$ 만 처리한 cell에서는 멜라닌 생성이 control 대비 $379 \pm 1.8 \%$ 증가하였으나, hexane 분획물에서는 멜라닌 생성이 $301 \pm 2.3 \%$, ethyl acetate 분획물에서는 $311 \pm 2.1 \%$, butanol 분획물에서는 $331 \pm 2.7 \%$ 증가하여 꾸지뽕나무 가지 분획물 의 멜라닌 생성 억제 효과를 확인할 수 있었다. 그러나 water 에서는 유의성 있는 멜라닌 생성 억제 효과를 확인할 수 없었 다(Figure 6B). 본 결과를 통하여 꾸지뽕나무 가지 분획물 중 hexane, ethyl acetate, butanol은 $1 \mathrm{ppm}$ 의 농도에서 $\mathrm{B} 16 \mathrm{~F} 10$
세포에 세포 독성 없이 멜라닌 합성을 억제함으로써 미백 활성을 가지는 것으로 사료된다.

\section{Conclusion}

최근 생활수준 향상, 평균수명 증가, 야외 활동의 활성화 등으로 인 해 기능성 화장품의 수요가 증가하는 추세이다. 또한 환경에 대한 관 심, 화학 약품 등의 부작용에 대한 우려 등으로 인해 그 어느 때보다 유 효 활성이 우수하면서도 안전한 천연물에 대한 관심이 고조되고 있다.

뽕나무과에 속하는 꾸지뽕나무(Cudrania tricuspidata)는 성 질이 따뜻하고, 독이 없으며 예로부터 잎은 식용으로 수피와 근 피는 약재로 많이 사용되었다. 한편 꾸지뽕나무의 성분연구를 통 해 xanthone류(Lee et al., 2005; Zou et al., 2004), flavonoid류, L-ascorbic acid와 rutin 등의 항산화 물질들이 많이 보고되었으 며 이러한 성분들은 항산화, 항염, 미백, 주름개선 등의 효과가 있 는 것으로 알려져 있다. 그러나 꾸지뽕나무 가지를 이용한 기능성 화장품 원료에 대한 연구는 부족한 실정이므로, 꾸지뽕나무 가지 추출물의 항산화 및 미백 효과를 검증하여 미백 기능성 화장품 소재를 개발하고자 본 연구를 진행하였다.

꾸지뽕나무 가지 $\mathrm{EtOH}$ 추출물을 용매분획하여 얻은 hexane, ethyl acetate, butanol, water 분획물 중 항산화 물질인 dihydroquercetin $7-\mathrm{O}-\beta-\mathrm{D}-$ glucopyranoside, dihydrokaempferol 7-O- $\beta-\mathrm{D}$-glucopyranoside, rutin이 ethyl acetate 및 butanol 분획물에서 존재함을 확인하였으며, 꾸 지뽕나무 가지 $\mathrm{EtOH}$ 추출물 $1 \mathrm{~g}$ 당 dihydroquercetin 7-O- $\beta$ -D-glucopyranoside $16.54 \mathrm{mg}$, dihydrokaempferol 7-O- $\beta$ -D-glucopyranoside $14.61 \mathrm{mg}$, rutin $34.65 \mathrm{mg}$ 이 각각 함유 되어 있었다. 
Radical 및 superoxide 관련 항산화능 평가 실험을 통해서 그 정도의 차이가 있으나, 꾸지뽕나무 가지 분획물 중 ethyl acetate 및 butanol 분획물에서 각각의 양성대조군과 유사한 항산화 활성을 나타냄을 확인하였으며, 특히 ethyl acetate 분획물이 가장 우수한 항산화 활성을 보였다. 이는 앞서 언급한 TLC 및 HPLC 결과와 유사한 경향을 보이며, ethyl acetate와 butanol 에 존재하는 dihydroquercetin 7-O- $\beta-\mathrm{D}$-glucopyranoside, dihydrokaempferol 7-O- $\beta-\mathrm{D}-$ glucopyranoside, rutin으로 인하여 뚜렷한 항산화 효과를 나타낸 것으로 사료된다.

미백 효과와 관련하여 tyrosinase 활성 억제 실험을 수행한 결과, ethyl acetate ( $\left.\mathrm{IC}_{50} 24.4 \mathrm{ppm}\right)$ 와 butanol $\left(\mathrm{IC}_{50} 88.3 \mathrm{ppm}\right)$ 분획물에 서 tyrosinase 활성 억제 효과를 확인할 수 있었고, melanin 생합성 억제 평가 실험에서는 hexane, ethyl acetate, butanol 분획물에서 멜라닌 생성이 억제되는 효과를 확인할 수 있었다.

이상의 실험결과를 종합해 볼 때, 꾸지뽕나무 가지의 ethyl acetate 및 butanol 분획물이 항산화 물질을 함유함으로써 항산화 효과를 근간으로 한 미백 기능성 화장품 원료로서의 개발 가능성을 확인하였다. 그러나 구체적인 세포 내 작용 기전 및 인체적용 시 동 일한 효능의 재현 가능성에 대한 연구가 부족하다는 한계점이 있으 며, 미백 이외에도 주름개선, 자외선 등 복합 기능성 화장품 원료에 대한 수요가 증가하고 있는 추세이므로, 이와 관련하여 다양한 기 능성 활성에 대한 추가 연구가 필요할 것으로 사료된다.

This work is part of the Hyo Sun Han's M.S. thesis at the Chung-Ang University, Seoul, Korea.

\section{References}

Andersen HR, Nielsen JB, Nielsen F, Grandjean P. Antioxidative enzyme activities in human erythrocytes. Clinical Chemistry, 43: 562-568, 1997.

Arnao MB, Cano A, Acosta M. The hydrophilic and lipophilic contribution to total antioxidant activity. Food Chemistry, 73: 239-244, 2001.

Cha JY, Kim HJ, Chung CH, Cho YS. Antioxidative activities and contents of polyphenolic compound of Cudrania tricuspidata. Journal of the Korean Society of Food Science and Nutrition, 28: 1310-1315, 1999.

Cha JY, Kim HJ, Cho YS. Effects of water-soluble extract from leaves of Morus alba and Cudrania tricuspidata on the lipid peroxidation in tissues of rats. Journal of the Korean Society of Food Science and Nutrition, 29: 531-536, 2000.
Cho EJ, Yokozawa T, Rhyu DY, Kim SC, Shibahara N, Park JC. Study on the inhibitory effects of Korean medicinal plants and their main compounds on the 1,1-diphenyl2-picrylhydrazyl radical. Phytomedicine, 10: 544-551, 2003.

Choi SR, You DH, Kim JY, Park CB, Kim DH, Ryu J. Antioxidant activity of methanol extracts from Cudrania tricuspidata Bureau according to harvesting parts and time. Korean Journal of Medicinal Crop Science, 17: 115-120, 2009.

Chon IJ, Lee SW, Cha JH, Han JH, Whang WK. Anti-oxidant compounds of Cudrania tricuspidata leaves. Yakhak Hoeji, 49: 416-421, 2005.

Fisher GJ, Talwar HS, Lin J, Voorhees JJ. Molecular mechanisms of photoaging in human skin in vivo and their prevention by all-trans retinoic acid. Photochemistry and Photobiology, 69: 154-157, 1999.

Jeong HJ, Lee SG, Lee EJ, Park WD, Kim JB, Kim HJ. Antioxidant activity and anti-hyperglycemic activity of medicinal herbal extracts according to extraction methods. Korean Journal of Food Science and Technology, 42: 571-577, 2010.

Jeong KS, Kim JD. A study on future trends of cosmetic industrial development: cosmeceuticals. The Journal of Skin Barrier Research, 1: 35-40, 1999.

Joo HY, Lim KT. Protective effect of glycoprotein isolated from Cudrania tricuspidata on liver in $\mathrm{CCl}_{4}$-treated $\mathrm{A} / \mathrm{J}$ mice. Korean Journal of Food Science and Technology, 41: 93-99, 2009.

Jung TH. Illustrated encyclopedia the fauna and flora of Korea: tracheophyta. Ministry of Education, Sejong, p1475, 1965.

Kang DG, Hur TY, Lee GM, Oh H, Kwon TO, Sohn EJ, Lee HS. Effects of Cudrania tricuspidata water extract on blood pressure and renal functions in NO-dependent hypertension. Life Sciences, 70: 2599-2609, 2002.

Kim HJ, Cha JY, Choi ML, Cho YS. Antioxidative activities by water-soluble extracts of Morus alba and Cudrania tricuspidata. Applied Biological Chemistry, 43: 148152, 2000.

Kim JY, Chung JH, Hwang I, Kwan YS, Chai JK, Lee KH, Han TH, Moon JH. Quantification of quercetin and kaempferol contents in different parts of Cudrania tricuspidata and their processed foods. Korean Journal 
of Horticultural Science \& Technology, 27: 489-496, 2009.

Kim MJ, Jung TK, Yoon KS. Anti-aging effects of prescription extracts containing Forsythia viridissima L. Journal of the Society of Cosmetic Scientists of Korea, 41: 85-96, 2015.

Kim MK, Kim JS, Jo BS, Kim JH, Lee IC, Lee MS, Cho YJ. Functional properties of walnut in cosmetics. Journal of Life Science, 21: 858-864, 2011.

Kim SE, Kim YH, Lee JT. Antioxidant activity and whitening efficacy of ethanolic extract of herb complex (Oenothera laciniata, Phellinus linteus and Glycyrrhiza uralensis Fischer). Journal of Investigative Cosmetology, 10: 2733, 2014.

Kim SH, Kim NJ, Choi JS, Park JC. Determination of flavonoid by HPLC and biological activities from the leaves of Cudrania tricuspidata Bureau. Journal of the Korean Society of Food Science and Nutrition, 22: 68$72,1993$.

Lee BW, Gal SW, Park KM, Park KH. Cytotoxic xanthones from Cudrania tricuspidata. Journal of Natural Products, 68: 456-458, 2005.

Lee IK, Song KS, Kim CJ, Kim HM, Oh GT, Yoo ID. Tumor cell growth inhibition and antioxydative activity of flavonoids from the stem bark of Cudrania tricuspidata. Applied Biological Chemistry, 37: 105-109, 1994.

Lee IK, Kim CJ, Song KS, Kim HM, Koshino H, Uramoto M, Yoo ID. Cytotoxic benzyl dihydroflavonols from Cudrania tricuspidata. Phytochemistry, 41: 213-216, 1996.

Lee JS, Han GC, Han GP, Kozukue N. The antioxidant activity and total polyphenol content of Cudrania tricuspidata. Journal of the East Asian Society of Dietary Life, 17: 696-702, 2007.

Lee SK, Mbwambo ZH, Chung H, Luyengi L, Gamez EJ, Mehta RG, Kinghorn AD, Pezzuto JM. Evaluation of the antioxidant potential of natural products. Combinatorial Chemistry \& High Throughput Screening, 1: 35-46, 1998.

Moure A, Cruz J. Franco D, Domínguez JM, Sineiro J, Domínguez H, Núñez MJ, Parajó JC. Natural antioxidants from residual sources. Food Chemistry, 72: 145-171, 2001.

Nam DE, Kim OK, Lee J. Therapeutic effects of Curdrania tricuspidata leaf extract on osteoarthritis. Journal of the Korean Society of Food Science and Nutrition, 42: 697-704, 2013.

Nomura T, Hano Y, Fujimoto T. Three new isoprenylated xanthines, cudraxanthone A, B, and C, from the root barks of Cudrania tricuspidata (Carr.) Bur. Heterocycles, 20: 213-218, 1983.

Omaye ST, Reddy KA, Cross CE. Effect of butylated hydroxytoluene and other antioxidants on mouse lung metabolism. Journal of Toxicology and Environmental Health, 3: 829-836, 1977.

Ottersen T, Vance B, Doorenbos NJ, Chang BL, el-Feraly FS. The crystal structure of cudranone, 2,6,3'-trihydroxy-4methoxy-2'-(3-methyl-2-butenyl)-benzophenone: a new antimicrobial agent from Cudrania cochinchinensis. Acta Chemica Scandinavica Series B: Organic Chemistry and Biochemistry, 31: 434-436, 1977.

Park JC, Choi JS, Choi JW. Effects of the fractions from the leaves, fruits, stems and roots of Cudrania tricuspidata and flavonoids on lipid peroxidation. Korean Journal of Pharmacognosy, 26: 377-384, 1995.

Ramarathnam N, Osawa T, Ochi H, Kawakishi S. The contribution of plant food antioxidants to human health. Trends in Food Science \& Technology, 6: 7582, 1995.

Seo SJ, Kong MR, Joo EY. Anti-aging and antioxidant activities of extracts from Liriope platyphylla fruits. Journal of Investigative Cosmetology, 9: 105-114, 2013.

Shim JS, Kwon YY, Hwang JK. The effects of panduratin A isolated from Kaempferia pandurata on the expression of matrix metalloproteinase-1 and type-1 procollagen in human skin fibroblasts. Planta Medica, 74: 239244, 2008.

Squadrito GL, Pryor WA. Oxidative chemistry of nitric oxide: the roles of superoxide, peroxynitrite, and carbon dioxide. Free Radical Biology and Medicine, 25: 392403, 1998.

Zou YS, Hou AJ, Zhu GF, Chen YF, Sun HD, Zhao QS. Cytotoxic isoprenylated xanthones from Cudrania tricuspidata. Bioorganic \& Medicinal Chemistry, 15: 1947-1953, 2004. 


\section{국문초록}

\section{꾸지뽕나무 가지 추출물을 이용한 미백 기능성 화장품 소재 개발}

한효선 ${ }^{1,2}$, 김수연 ${ }^{3}$, 임대진 $^{4}$, 황완균 $^{2 *}$

${ }^{1}$ 한국피부과학연구원, 서울, 한국

${ }^{2}$ 중앙대학교 약학과, 서울, 한국

${ }^{3}$ 두원공과대학교 뷰티아트과, 경기도 파주시, 한국

${ }^{4}$ 숭실사이버대학교 미용예술학과, 서울, 한국

목적: 본 연구는 꾸지뽕나무 가지 추출물의 미백 기능성 화장품 소재로서의 발전 가능성을 확인하는데 그 목적이 있다. 방법: TLC 및 HPLC 분석을 통해 꾸지뽕나무 분획물(헥산, 아세트산에틸, 부탄올, 물)의 항산화 물질 함유여부를 확인하였 고, 항산화 효과를 확인하기 위하여 DPPH, ABTS free radical 및 superoxide 소거 활성 시험을 진행하였다. 그리고 티로 시나제 억제율과 멜라닌 생합성률 확인 실험을 통해 꾸지뽕나무의 미백 효능을 확인하였다. 결과: Radical 및 superoxide 관련 항산화능 평가 실험을 통해서 그 정도의 차이가 있으나, 꾸지뽕나무 가지 분획물 중 아세트산에틸 분획물 및 부탄올 분획물에서 각각의 양성대조군과 유사한 항산화 활성을 나타냄을 확인하였으며, 특히 아세트산에틸 분획물이 가장 우수한 항산화 활성을 보였다. 미백 효과와 관련하여 티로시나제 활성 억제 실험을 수행한 결과, 아세트산에틸 분획물( $\mathrm{IC}_{50} 24.4$ $\mathrm{ppm})$ 과 부탄올 분획물 $\left(\mathrm{IC}_{50} 88.3 \mathrm{ppm}\right)$ 에서 티로시나제 활성 억제 효과를 확인할 수 있었고, 멜라닌 생합성 억제 평가 실험 에서도 아세트산에틸, 부탄올 분획물에서 멜라닌 생성이 농도의존적으로 줄어들었다. 결론: 상기 실험결과를 통해, 꾸지뽕 나무 가지 추출물은 향후 항산화 및 미백 효과를 가지고 있는 기능성 화장품 소재로의 발전이 가능할 것으로 사료된다.

핵심어: 꾸지뽕나무, 항산화, 티로시나제, 멜라닌, 미백 화장품

\section{참고문헌}

김미경, 김진성, 조분성, 김정환, 이인철, 이명섭, 조영제. 호두의 화장품 기능성. 생명과학회지, 21: 858-864, 2011. 김미진, 정택규, 윤경섭. 연교를 함유한 처방단 추출물의 항노화 효과. 대한화장품학회지, 41: 85-96, 2015.

김성환, 김남재, 최재수, 박종철. 꾸지뽕나무 잎의 생리활성 및 HPLC에 의한 성분의 정량. 한국식품영양과학회지, $22: 68-$ $72,1993$.

김수은, 김영훈, 이진태. 천연복합물(애기달맞이꽃, 상황버섯, 감초) 에탄올 추출물의 항산화 활성 및 피부미백 효능. 대한미용 학회지, 10: 27-33, 2014.

김진영, 정진호, 황인, 권용석, 채정기, 이계한, 한태호, 문제학. 꾸지뽕나무의 부위별 및 가공식품에 함유된 Quercetin과

Kaempferol의 정량. 원예과학기술지, 27: 489-496, 2009.

김현정, 차재영, 최명락, 조영수. 뽕나무(Morus alba)와 꾸지뽕나무(Cudrania tricuspidata)의 수용성 추출물에 의한 항산화 활성. 한국응용생명화학회지, 43: 148-152, 2000.

남다은, 김옥경, 이정민. 관절염 실험모델에서 꾸지뽕나무 추출물의 골관절염 억제효과 연구. 한국식품영양과학회지, 42 : 697-704, 2013.

박종철, 최재수, 최종원. 꾸지뽕나무 잎, 열매, 줄기 및 뿌리의 분획물과 플라보노이드 화합물이 흰쥐의 과산화지질 함량에 미

치는 영향. 생약학회지, 26: 377-384, 1995.

서수정, 공미란, 주은영. 맥문동(Liriope platyphylla) 열매 추출물의 항노화 효과 및 항산화 활성. 대한미용학회지, 9: 105-

$114,2013$.

이인경, 송경식, 김창진, 김환묵, 오구택, 유익동. 꾸지 뽕나무로부터 분리한 flavonoid계 화합물의 암세포성장 저해 및 항산화 
활성. 한국응용생명화학회지, 37: 105-109, 1994.

이진식, 한갑조, 한경필, 코즈쿠에 노부유키. 꾸지뽕나무(Cudrania tricuspidata Bureau)의 총 폴리페놀 함량 및 항산화 활성.

동아시아식생활학회지, 17: 696-702, 2007.

전인주, 이성완, 차자현, 한정훈, 황완균. 구지뽕나무 잎의 항산화 성분. 약학회지, 49: 416-421, 2005.

정경숙, 김주덕. 미래 화장품 산업개발 방향에 관한 연구: 기능성 화장품. 한국피부장벽학회지, 1: 35-40, 1999.

정태현. 한국동식물도감: 식물편(목·초본류). 교육부, 세종, p1475, 1965.

정현진, 이성규, 이은주, 박우동, 김종부, 김현정. 약용식물의 추출방법에 따른 항산화 및 항당뇨 활성. 한국식품과학회지, 42 :

571-577, 2010.

주헌영, 임계택. 생쥐에 있어서 꾸지뽕 당단백질의 간보호 효과. 한국식품과학회지, 41: 93-99, 2009.

차재영, 김현정, 정정한, 조영수. 꾸지뽕나무(Cudrania tricuspidata)의 폴리페놀 화합물 함량과 항산화 활성. 한국식품영양과 학회지, 28: 1310-1315, 1999.

차재영, 김현정, 조영수. 뽕나무(Morus alba) 및 꾸지뽕나무(Cudrania tricuspidata) 잎의 수용성 추출물이 흰쥐 각 조직중의 지질 과산화물 함량에 미치는 영향. 한국식품영양과학회지, 29: 531-536, 2000.

최소라, 유동현, 김종엽, 박춘봉, 김대향, 류정. 이용부위 및 채취시기에 따른 꾸지뽕나무 메탄올 추출물의 항산화성. 한국약 용작물학회지, 17: 115-120, 2009. 


\section{中文摘要}

\section{柘树枝提取物的美白化妆品原料开发}

韩孝仙 ${ }^{1,2}$, 金秀形 ${ }^{3}$, 林大震 $^{4}$, 黃完均 $2^{*}$

1韩国皮肤科学研究院, 首尔, 韩国

${ }^{2}$ 中央大学校药学院, 首尔, 韩国

${ }^{3}$ 斗源工科大學 美容艺术科, 京畿道 坡州市, 韩国

崇實Cyber大學 美容艺术科, 首尔, 韩国

目的: 探讨柘树枝提取物作为美白功效性化妆品原料的可行性。方法: 利用TLC和HPLC分析柘树枝几种溶剂（正己烷 乙酸乙酯、正丁醇、水) 萃取物是否含有抗氧化物质，为了进一步确认萃取物的抗氧化效果进行了DPPH，ABTS free radical以及超氧阴离子自由基清除活性实验。另外为了确认柘树枝提取物的美白效能进行了酪氨酸酶抑制率和 黑色素合成率的实验。结果: 通过radical以及 超氧阴离子自由基清除活性实验, 确认了柘树枝乙酸乙酯萃取物以及正 丁醇萃取物分别与它的阳性对照组具有相似的抗氧化活性, 特别是乙酸乙酯萃取物具有最优秀的抗氧化活性。为了确 认美白效能评价进行酪氨酸酶抑制实验, 其结果显示在萃取物中只有乙酸乙酯（IC $24.4 \mathrm{ppm})$ 和 正丁醇萃取物（IC $88.3 \mathrm{ppm}$ ）具有酪氨酸酶抑制效果。通过黑色素抑制实验, 也确认随着乙酸乙酯、正丁醇萃取物浓度的增加降低黑色 素的形成。结论: 通过以上结果, 柘树枝提取物作为抗氧化和美白效能的化妆品原料充分具有发展可行性。

关键词: 柘树，抗氧化，酪氨酸酶，黑色素，美白化妆品 